\title{
High solar radiation hinders tree regeneration above the alpine treeline in northern Ecuador
}

\author{
Maaike Y. Bader • Isabel van Geloof • \\ Max Rietkerk
}

Received: 13 March 2006/ Accepted: 29 August 2006/Published online: 27 September 2006

(C) Springer Science+Business Media B.V. 2006

\begin{abstract}
Many tropical alpine treelines lie below their climatic potential, because of natural or anthropogenic causes. Forest extension above the treeline depends on the ability of trees to establish in the alpine environment. This ability may be limited by different factors, such as low temperatures, excess solar radiation, competition, soil properties, dispersal ability, and fires. In this paper we address the following two questions: Do trees regenerate above the present treeline, and what are the inhibiting factors for tree establishment? To answer these questions we described the spatial pattern of recent tree establishment below and above the present treeline in northern Ecuador. Also, we experimentally transplanted seedlings into the alpine vegetation (páramo) and the forest, and investigated the effect of shade, neighboring plants, and substrate on their survival. The number of naturally occurring tree sprouts (seedlings, saplings and ramets) was highest just outside the forest, and decreased with distance to the forest edge. However, only two
\end{abstract}

M. Y. Bader $(\bowtie) \cdot$ I. van Geloof

Centre for Geo-Information, Wageningen University, P.O. Box 47, 6700 AA Wageningen, The Netherlands e-mail: maaike.bader@wur.nl/bmaaike@yahoo.com

M. Rietkerk

Department Environmental Sciences, Copernicus Institute, Utrecht University, P.O. Box 80115, 3508

TC Utrecht, The Netherlands species that were radiation-tolerant made up these high numbers, while other species were rare or absent in the páramo. In the forest, the species diversity of sprouts was high and the abundance per species was relatively low. The transplanted seedlings survived least in experimental plots without artificial shade where neighboring plants were removed. Seedling survival was highest in artificially shaded plots and in the forest. This shade-dependence of most tree species can strongly slow down forest expansion toward the potential climatic treeline. Due to the presence of radiation-tolerant species, the complete lack of forest expansion probably needs to be ascribed to fire. However, our results show that natural processes can also explain both the low position and the abruptness of tropical treelines.

Keywords Cloud forest $\cdot$ Cold-induced photoinhibition $\cdot$ Fire $\cdot$ Páramo $\cdot$ Positive feedback switch $\cdot$ Transplantation experiment

\section{Introduction}

On most many tropical mountains the actual treeline lies at a lower altitude than the potential climatic treeline (Kessler 1995; Miehe and Miehe 1994). In this paper we use the term treeline to refer to the actual upper boundary of closed forest. The potential climatic treeline then 
delimits the potential forest extent under the current climatic conditions. The altitude of this potential treeline is unknown, however, because both historical treeline dynamics and the ecological drivers of current dynamics are not well understood (Kessler 2002; Wille et al. 2002).

In general, two possible explanations for the positional discrepancy between the actual and the potential treeline exist. First, treelines may still not have moved up to their potential altitude from previously lower positions (e.g. in the last ice-age) due to the slowness or absence of natural colonization (Holtmeier 1994; Slayter and Noble 1992; Wardle and Coleman 1992). Second, treelines may have been moved down from previously higher positions due to human activities, especially fire (Ellenberg 1996; Hemp and Beck 2001; Kessler 1995; Laegaard 1992; Miehe and Miehe 1994; Wesche et al. 2000; Wille et al. 2002). The latter, anthropogenic scenario now dominates the literature as the explanation for the relatively low treeline positions in the Ecuadorian Andes and in most other tropical mountain areas.

Temperature is generally considered to be the main natural determinant of treeline position (Körner and Paulsen 2004), and treelines are therefore expected to react strongly to global warming (Kullman 2001; Kupfer and Cairns 1996). However, if a treeline lies below its climatic potential, for whatever reason, the forest could extend upwards even if there is no increase in temperature. Forest extension, whether due to climatic change or not, depends on the ability of trees to establish above the present treeline. This ability may be temperature dependent for some species, but other limitations, such as excess solar radiation, competition from neighbors, unfavorable soil properties, low dispersal ability, and fire could be equally important.

Treelines in tropical mountains experience very high solar radiation levels, due to the combination of low latitude and high altitude. Excess radiation can have negative effects on plants, causing overheating, desiccation, and photoinhibition (Barber and Andersson 1992; Long et al. 1994). These negative effects are aggravated by low temperatures (Ball et al. 1991; Close et al. 2000; Huner et al. 1998; Krause 1994), especially frost, which can occur year-round at night at tropical treelines. Cold-induced photoinhibition has been recognized as a limitation for tree seedling establishment at treelines in Australia and North America (Ball et al. 1991; Germino and Smith 1999; Germino et al. 2002).

Competition from surrounding vegetation could also limit tree seedling establishment (Wardle and Coleman 1992), but facilitation tends to gain relative importance in more stressful environments such as alpine areas (Callaway et al. 2002; Choler et al. 2001; Pugnaire and Luque 2001). At least at some temperate treelines, seedlings seem to benefit rather than suffer from surrounding alpine vegetation (Germino et al. 2002; Maher et al. 2005; Smith et al. 2003), but for tropical treelines this balance is yet unknown. In the páramo, the alpine vegetation of the northern Andes, plant cover is often very dense and over half a meter high, and may therefore compete heavily with tree seedlings, although it could also offer protection.

In this paper we address the following two questions: do trees regenerate above the present treeline, and what factors limit tree establishment? Based on the reasons given above, we suspected that excess solar radiation is a main limitation for tree regeneration above tropical treelines. We therefore hypothesized that only radiation-tolerant tree species could naturally regenerate in the páramo, and that other species could survive here only if extra shade were provided artificially, while removing shade from neighboring plants would decrease survival. To test the first hypothesis we studied the spatial pattern of recent tree establishment below and above the present treeline in northern Ecuador. To test the latter we experimentally transplanted seedlings into the páramo, where treatments consisted of providing shade and clearing neighbors, and into the forest. We also hypothesized that tree seedlings did not depend on the organic, moss-covered forest substrate, but could establish equally well in the mineral páramo soil. To test this, one treatment in the forest consisted of removing the thick organic layer, thereby exposing the mineral soil.

Understanding the natural dynamics and the regeneration requirements of cloud forests at the treeline can have important implications for 
reforestation or ecological restoration in páramo areas. Our results will also help to understand different reasons why treelines can lie below their climatic potential and why they are usually abrupt, and offer insight in the treeline dynamics we can expect due to climatic change (Slayter and Noble 1992).

\section{Study area}

The studied treeline is part of the private biological reserve Guandera Biological Station, situated on the inner flanks of the eastern Cordillera in northern Ecuador (N $0^{\circ} 36^{\prime}, \mathrm{E}-77^{\circ} 42^{\prime}$, Fig. 1). The area is of volcanic origin and has deep dark humic Andosols, developed in old volcanic ashes. Precipitation is high all year round. Average temperatures are low and fluctuate little through the year, but diurnal temperature fluctuations are strong (Fig. 2).

The treeline in this area is an abrupt boundary between upper montane cloud forest (Hamilton et al. 1995) and tussock grass páramo (Hofstede et al. 2003) (Fig. 3). It varies in altitude from ca. 3,500 to $3,700 \mathrm{~m}$ above sea level (asl), and its position has been stable for at least 40 years, as evidenced by historical aerial photographs.

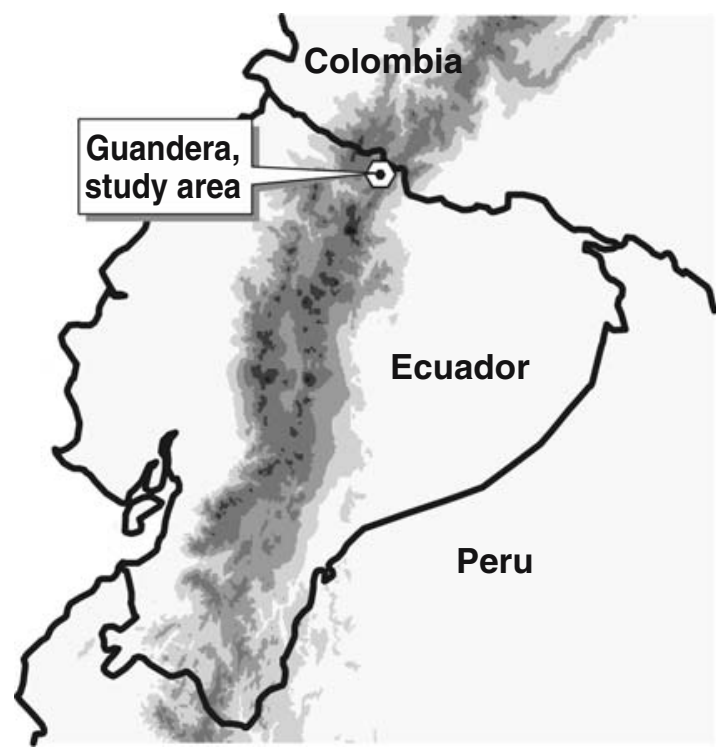

Fig. 1 Map of Ecuador showing the location of the study area. Elevation data: GTOPO30 (USGS, 1996)

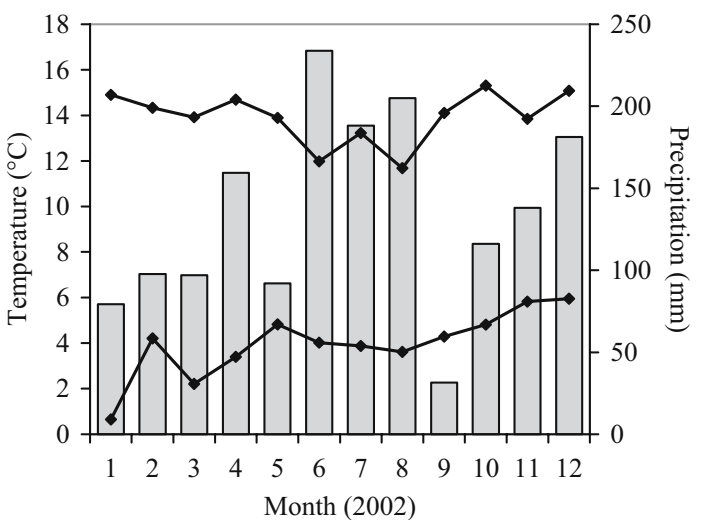

Fig. 2 Climate of Guandera in 2002, a year with normal weather conditions. Mean maximum and minimum daily temperature at $2 \mathrm{~m}$ (lines) and total precipitation per month (bars). Data from weather station at Guandera Biological Station, open area in cloud forest at ca. $3370 \mathrm{~m}$ asl

Patches of forest are found up to $100 \mathrm{~m}$ from the closed forest boundary in small topographical depressions and valleys. These patches are also at least 40 years old.

The reserve is named after the tree species Clusia flaviflora, locally called guandera, a large and distinctive tree with abundant aerial roots, which dominates parts of the forest. Other parts of the forest have a mixed canopy composed mainly of the tree species Ilex colombiana, Weinmannia cochensis, Miconia tinifolia, Clusia flaviflora, and Gaiadendron punctatum (authorities in Table 1). The most common shrub species in the understory are various Ericaceae, Miconia chlorocarpa Cogn., Desfontainia espinosa Ruiz and Pav. and Myrsine sp. At the forest edge large Diplostephium shrubs and caulescent Blechnum ferns are the most common elements. The forest floor is totally covered with moss, including Sphagnum species, especially at the forest edge, and has a peaty organic layer of 30-100 cm on top of the dark mineral soil.

The páramo is dominated by large tussock grasses (Festuca sp., Calamagrostis sp.), which generally form a dense layer of about $0.5 \mathrm{~m}$ high. The terrestrial Bromeliad Puya hamata L.B.Smith and the tall (up to $4 \mathrm{~m}$ ) stem rosette Espeletia pycnophylla Cuatrec. are abundantly interspersed in the grass. There is no animal husbandry in the páramo, nor has there been in the past (local 
Fig. 3 Photograph of the study area in Guandera Biological Station in northern Ecuador. This part of the treeline is situated at ca. $3,650 \mathrm{~m}$ asl. In the foreground and on the left there is tussock grass páramo with abundant Espeletia pycnophylla stem rosettes, and on the right there is upper montane cloud forest, locally known as the 'ceja andina'

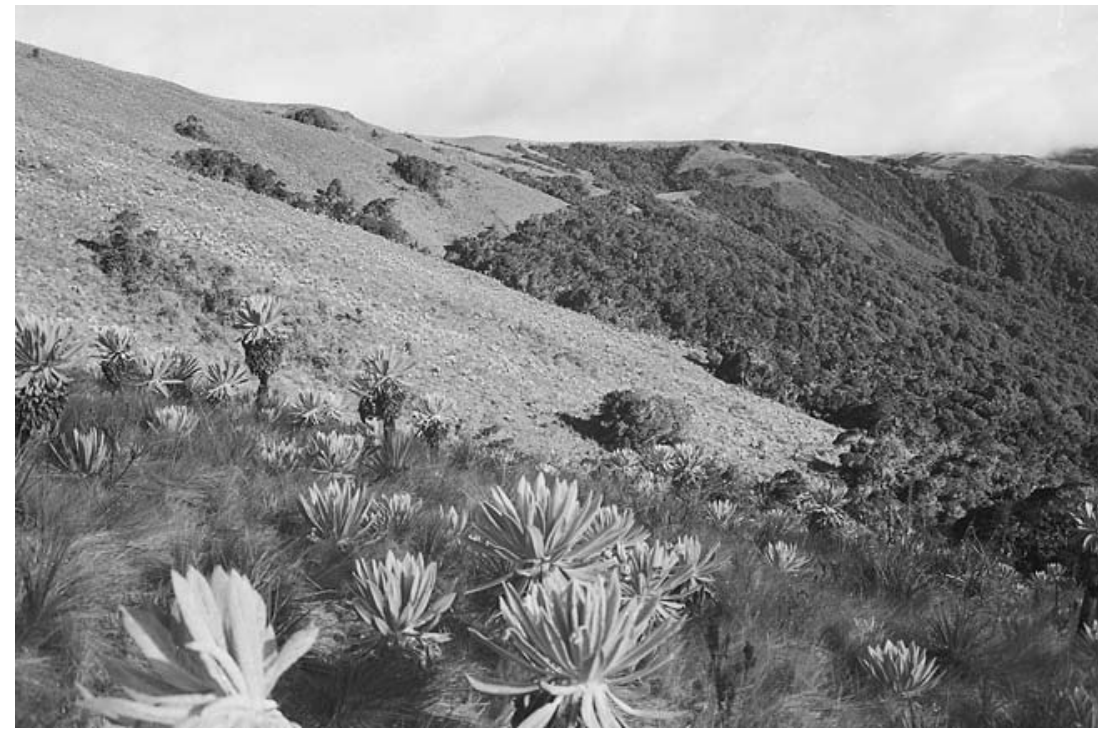

Table 1 Number of sprouts found in $30 \mathrm{~m}^{2}$ plots in forest and páramo: mean number per plot and standard deviation

\begin{tabular}{|c|c|c|c|c|}
\hline \multirow[t]{2}{*}{ Species } & \multirow[t]{2}{*}{ Family } & \multicolumn{2}{|c|}{ Mean (SD) nr of sprouts } & \multirow{2}{*}{$\begin{array}{l}\mathrm{Nr} \text { of plots with } \\
\text { species in canopy }\end{array}$} \\
\hline & & Páramo (125 plots) & Forest (40 plots) & \\
\hline $\begin{array}{l}\text { Gaiadendron punctatum } \\
\text { (Ruiz \& Pavón) G.Don. }\end{array}$ & Loranthaceae & $17.6(38.1)$ & $2.0(3.5)$ & 26 \\
\hline Weinmannia cochensis Hieron. & Cunoniaceae & $8.4(25.4)$ & $0.7(1.5)$ & 35 \\
\hline $\begin{array}{l}\text { Clusia flaviflora Engl. and } \\
\text { C. multiflora Kunth }\end{array}$ & Clusiaceae & $2.0(6.2)$ & $7.6(10.8)$ & 21 \\
\hline Miconia tinifolia Naudin & Melastomataceae & $1.1(2.8)$ & $4.4(4.2)$ & 31 \\
\hline Hedyosmum cumbalense Swartz. & Chloranthaceae & $0.5(2.5)$ & $2.2(4.6)$ & 8 \\
\hline Ilex colombiana Cuatrec. & Aquifoliaceae & $0.5(1.8)$ & $2.0(3.2)$ & 31 \\
\hline Escallonia myrtilloides L.F. & Escalloniaceae & $0.0(0.2)$ & $0.1(0.3)$ & 2 \\
\hline Clethra ovalifolia Turcz. & Clethraceae & - & - & 1 \\
\hline Oreopanax cf. confusus Marschal. & Araliaceae & - & - & 4 \\
\hline
\end{tabular}

The last column is the number of forest plots (total 40) where the tree species was present in the canopy. Two species of Clusia occur in the study area, but these were not distinguished in this study

people, pers. comm.), but fires are lit every 3-6 years because of the traditional belief that burning the páramo will induce rainfall, and due to carelessness or arson.

\section{Methods}

\section{Natural regeneration pattern}

To describe the pattern of natural tree regeneration 20 transects were laid out from $10 \mathrm{~m}$ below to $85 \mathrm{~m}$ above the treeline (distances along the slope). Eight plots of $5 \times 6 \mathrm{~m}$ were located along each of these transects, with the lower boundaries of the plots at $-10 \mathrm{~m},-5 \mathrm{~m}, 0 \mathrm{~m}, 5 \mathrm{~m}, 12 \mathrm{~m}, 20 \mathrm{~m}$, $40 \mathrm{~m}$, and $80 \mathrm{~m}$ above the treeline. Additionally, one set of five plots was located further (over $300 \mathrm{~m}$ ) above the treeline. Within all these plots all tree seedlings, saplings and ramets up to $1.4 \mathrm{~m}$ in height were counted (ramets principally of Gaiadendron punctatum, a species with strong clonal distribution). We will use the term sprouts to refer to seedlings, saplings and ramets together. In each the forest plot we also estimated the canopy cover of each tree species. 
Transplantation experiment

To test what factors may be limiting the regeneration of different tree species above the treeline, we transplanted tree seedlings to positions below and above the treeline. In the páramo seedlings were planted in 56 plots in a randomized-complete-blocks design. Each block contained four plots (ca. $1 \times 3 \mathrm{~m}$ in size and $25 \mathrm{~m}$ apart) with a different treatment in each plot: cleared neighboring plants, shaded with a shade tent, both cleared and shaded, and control. A total of 14 blocks were established at different distances from the treeline (between $3 \mathrm{~m}$ and $170 \mathrm{~m}$ ), and each distance was represented by two blocks (ca. $500 \mathrm{~m}$ apart). The shade tents were made from black $80 \%$ shade cloth. Neighbors were cleared to approximately $0.5 \mathrm{~m}$ around the seedlings. Seven seedlings were planted in each páramo plot.

In the forest seedlings were planted in 12 plots in a randomized-complete-blocks design with two treatments: undisturbed forest substrate (moss), and cleared organic layer (revealing the underlying black soil). Two blocks were established (ca. $500 \mathrm{~m}$ apart), each block containing three plots of both treatments, and both blocks were situated between $5 \mathrm{~m}$ and $20 \mathrm{~m}$ below the treeline. Eight seedlings were planted in each forest plot.

Seedlings $(3-50 \mathrm{~cm}$ tall) of eight tree species were included in the experiment, because we expected species-specific responses. Seedlings were collected in the forest near the treeline, and were generally planted the same day. They were easily pulled out of the moss and organic material of the forest floor, generally with no or little damage to the roots. Seedlings were collected in numbers roughly proportional to their occurrence in the forest, so rare species were planted in small numbers. The height and survival of the seedlings were assessed after 2, 6, 18, and 30 months. As an exception, Gaiadendron seedlings were assessed only once, 12 months after they were planted, because these were planted at a later date. These seedlings came from a nearby nursery (at ca. $3350 \mathrm{~m}$ asl), because they were too rare in the forest to be collected in sufficient numbers.

Between the 6-month and the 18-month measurements we found very little additional mortality inside the shade tents. We therefore expected little additional mortality in the last year, and to gain more information from the experiment we decided to test the effect of exposure to radiation on established seedlings. To this end some of the tents were removed. Thereby 4 of the 14 'cleared and shaded' treatments became 'cleared' treatments, and 6 of the 14 'shaded' treatments became 'control' treatments.

To assess the effect of the treatments on the microclimate, air and soil temperatures were measured. Air and topsoil temperatures were recorded every $2 \mathrm{~min}$ in forest moss and in all páramo treatments during 7 days. During these days the weather was variable, with sunny and cloudy periods, including some light rain. We used HOBO H8 Outdoor 4-Channel External Data Loggers (Onset Corporation) with external temperature probes. Temperature probes were installed at $15 \mathrm{~cm}$ above ground and at $3 \mathrm{~cm}$ below ground. Those above ground were protected from direct sunlight by small roofs made from disposable aluminum muffin tins lined with Styrofoam. Measurements were replicated (two sets of measurement series for each of the 4 treatments), but due to technical failure only one measurement series per treatment was usable. Soil temperatures at $12 \mathrm{~cm}$ below ground were measured once in each plot at the end of the experiment using a digital steel thermometer $\left(1^{\circ} \mathrm{C}\right.$ accuracy, $0.1^{\circ} \mathrm{C}$ resolution).

\section{Results}

Natural regeneration pattern

The number of naturally occurring sprouts was highest in páramo plots just outside the forest, and decreased with distance from the forest edge (Fig. 4). The high numbers in the páramo were due to the abundance of Gaiadendron ramets and Weinmannia seedlings, which were both relatively rare in the forest. The numbers of both Gaiadendron and Weinmannia sprouts in the páramo correlated negatively with the distance from the forest edge (Spearman's correlation of rank coefficients: $R=-0.71$ and $R=-0.60$, $P<0.01)$. Other species occurred in too low 


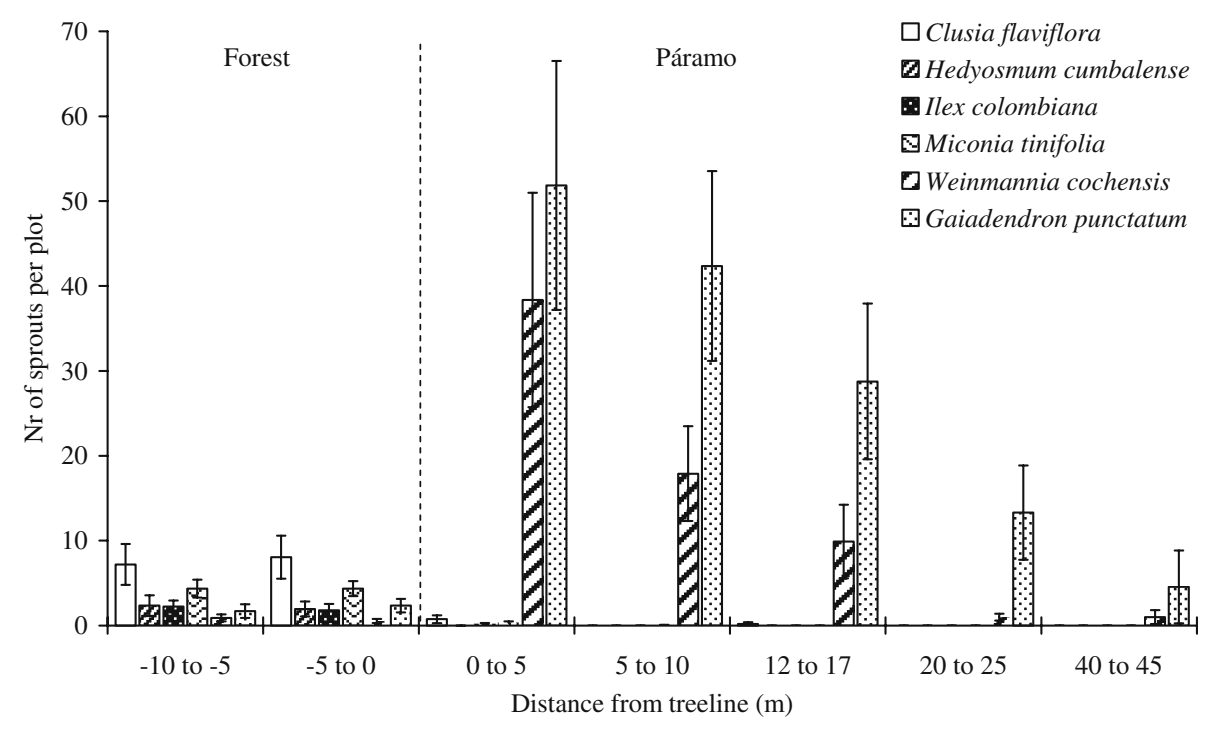

Fig. 4 Mean number of naturally occurring sprouts (including seedlings and ramets) in $30 \mathrm{~m}^{2}$ plots at different distances from the forest edge. Each bar represents the mean of 20 plots, error bars represent the standard error. Not shown are sprout numbers in plots at $80-85 \mathrm{~m}$ and at $>300 \mathrm{~m}$, because no sprouts occurred here numbers in the páramo to allow calculating such a correlation. Inside the forest the species diversity of sprouts was high; seven species were found, but numbers were relatively low (Table 1 and Fig. 4). Seedlings of Diplostephium (Asteraceae) were also common in the páramo, but these were not included in this part of the study because this species is not a tree but a large (up to $4 \mathrm{~m}$ ) shrub. However, because of its expected insensitivity to high radiation levels, this species was included in the transplantation experiment.

The total number of plots where a species was found in the canopy correlated positively (Spearman's $R=0.80 ; P<0.01$ ) with the total number of sprouts of this species (in all plots in both forest and páramo) (Table 1). For most of the common species, the average canopy cover of that species correlated positively with the total number of sprouts of that species per transect (Spearman's R for Gaiadendron: $R=0.45$, $P<0.05$; Clusia: $R=0.74, P<0.01$; Miconia: $R=0.60, \quad P<0.01 ; \quad$ Hedyosmum: $R=0.68$, $P<0.01)$. In contrast, in only one case did canopy cover per transect for a species correlate positively with the number of sprouts of another species (Clusia cover with Hedyosmum sprouts: Spearman's $R=0.63, P<0.05)$.

\section{Transplantation experiment}

The transplanted seedlings had the lowest overall survival rate in the cleared plots without shade, followed by the control (Fig. 5). The artificially shaded plots and those in the forest all had relatively high seedling survival, and after 18 months there was no significant difference between these treatments (Fig. 5). Accordingly, substrate type had no effect in the forest. At the 2-month measurement, survival did not yet differ between plots, although the health of the seedlings already predicted the differences found later. The removal of shade, 18 months after planting, had a significant negative effect on the survival of the seedlings that had survived so far both in the treatment with and without neighboring plants (two-way ANOVA, using the arcsine transformed survival per plot as the dependent variable, $P<0.05)$. There was no correlation between the distance from the treeline and survival of the sprouts (Spearman's $R=-0.05$ for survival after 30 months), and treatments had the same effects at all distances from the treeline (no block effect in ANOVA).

The survival after transplantation differed between species (one-way ANOVA, $P<0.01$ ), and 


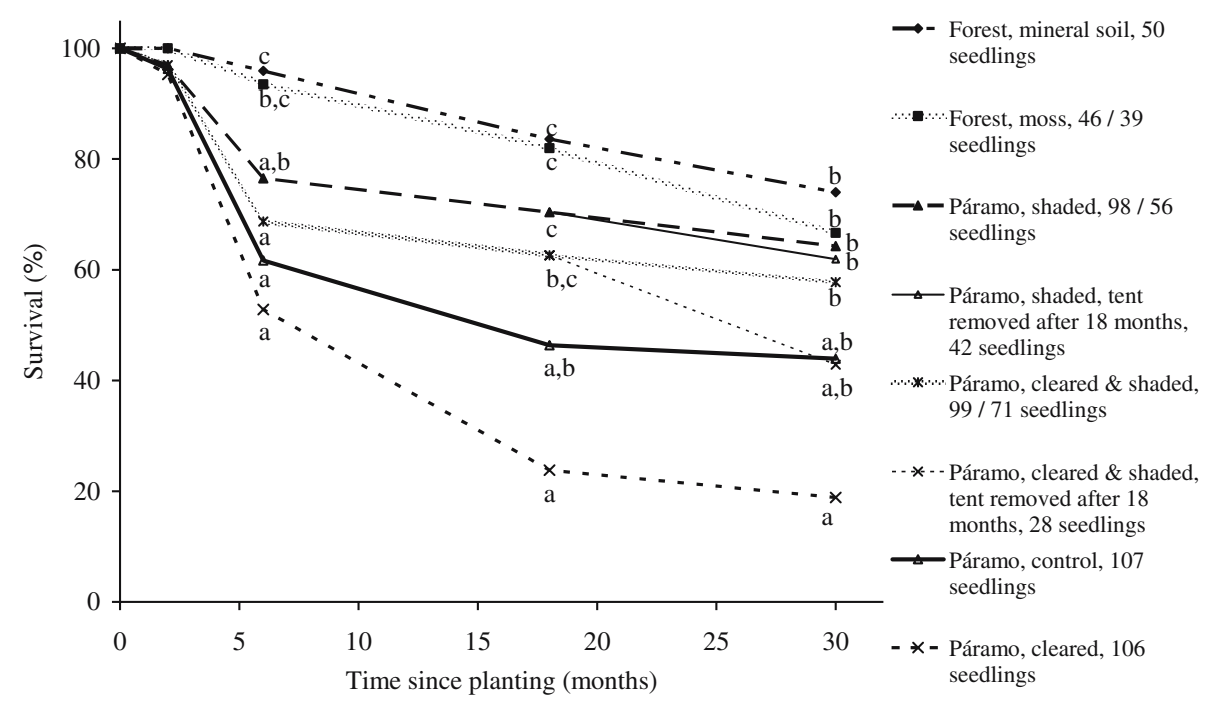

Fig. 5 Survival of all transplanted seedlings through time in the different treatments. Different letters indicate significant $(P<0.05)$ differences between treatments, per measuring time, according to a one-way ANOVA and Bonferroni post-hoc test, using the arcsine transformed survival per plot as the dependent variable. At 18 months part of the plots with shade treatments were

species responded differently to treatments (twoway ANOVA, interaction term: $P<0.01$ ) (Fig. 6). Seedlings of Clusia and Diplostephium had the highest overall survival rates (Bonferroni post-hoc test, $P<0.01$ ), but Clusia survived much less in the treatments without shade, while Diplostephium indeed appeared to be rather insensitive to the different treatments. Seedlings of Ilex and Gaiadendron had lower overall survival rates, but while survival of Ilex seedlings did not differ between treatments, Gaiadendron seedlings survived much less in the cleared plots without shade, while in the plots where páramo neighbors were left intact they had a higher survival. Species not included in Fig. 6 were Miconia chlorocarpa, M. tinifolia, Oreopanax sp., and Weinmannia cochensis. These were planted in numbers too low to allow detection of a speciesspecific response.

Seedlings had hardly grown in 2.5 years; in fact many had decreased in size due to damage to the upper part of stems and leaves, or due to a rise in the measurement base: fast growing moss in the forest. The types of damage observed were discoloration and subsequent shedding of leaves, changed: tents were removed. Therefore the graph is split in two at this point. The number of seedlings involved in each treatment is shown in the legend, and a second number is the number of seedlings (both dead and alive) still in this treatment after 18 months (in the forest a plot in moss was lost after 18 months). The seedlings that were planted at 18 months are not included

drying out of leaves and stems, some wilting, and occasionally some infections by fungi or other plant pathogens (rot). Often, only exposed parts of leaves showed discoloration or senescence, suggesting direct damage from radiation. No insects or traces of browsing were observed on the seedlings. The average length increase of the surviving seedlings was $-3 \mathrm{~cm}$, so a decrease. Of the 316 surviving seedlings, only 71 had grown more than $1 \mathrm{~cm}, 156$ had "grown" less than $-1 \mathrm{~cm}$, and 89 had the same size as at planting (a change in size of $1 \mathrm{~cm}$ or less is not considered growth, because of the measurement accuracy). Only 12 of the larger seedlings had grown more than $10 \mathrm{~cm}$, eight of which were Diplostephium. Expressed relative to the stem size at planting, average growth of surviving seedlings was $-9 \%, 160$ seedlings had "grown" less than $-10 \%$, and only 84 seedlings had grown more than $10 \%$. Growth differed between treatments; relative growth of surviving seedlings was lowest $(-25 \%$ to $-13 \%)$ in the forest plots and in the plots without artificial shade, and highest $(25 \%$ and $3 \%)$ in plots with artificial shade (oneway ANOVA and Bonferroni post-hoc test, $P<0.01)$. 


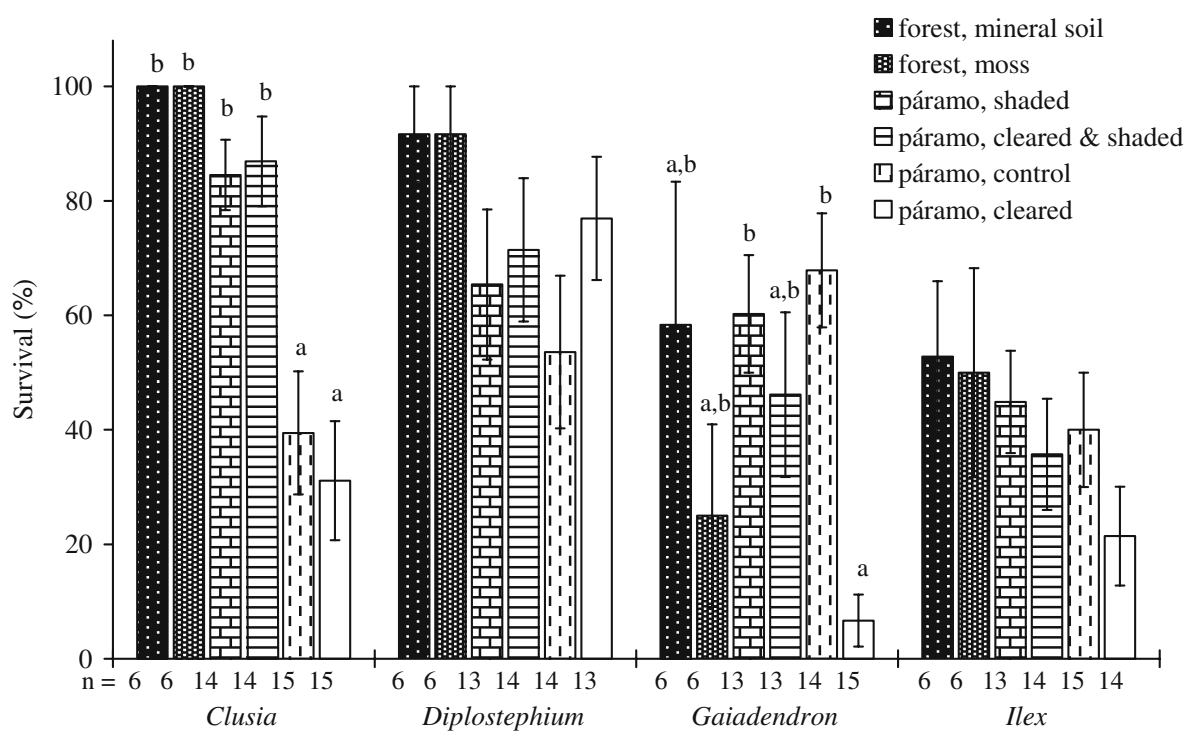

Fig. 6 Survival of transplanted seedlings after 18 months (Clusia, Diplostephium and Ilex) or after 12 months (Gaiadendron). The order of the treatments reflects a decrease in the overall seedling survival (all species together, Fig. 5). Bars represent the mean of the plots, error bars represent the standard error. Most plots contained 1-3 seedlings of a species and the number of

plots involved is shown under each bar. Diplostephium sp. and Ilex do not react significantly to the treatments, in contrast to Clusia and Gaiadendron. For the latter species different letters indicate significant $(P<0.05)$ differences between treatments, per species (one-way ANOVA and Bonferroni post-hoc test per species)

Air and topsoil temperatures were similar in the four páramo treatments, but differed between páramo and forest (Table 2). Still, also the treatments in the páramo caused some differences that may have affected the performance of the seedlings. The maximum topsoil temperature was higher in the cleared plot and to a lesser extent in the cleared and shaded plot, and minimum topsoil temperatures were lower in both these treatments compared to the páramo treatments without clearing. The bare soil surface in the unshaded

cleared plots was also observed to be rather dry, and there was hardly any reinvasion by herbs or tussock grasses. In contrast, beneath the shade tents a ground cover of moss indicated a moister microclimate. Another treatment effect that could have affected seedlings is the higher minimum air temperature in the shaded plot (Table 2). However, in the cleared and shaded plot the minimum air temperature was the same as in the unshaded plots, and the maximum air temperature varied without any consistent relation-

Table 2 Temperatures $\left({ }^{\circ} \mathrm{C}\right)$ in the different treatments of the transplantation experiment

\begin{tabular}{lllccccc}
\hline & ${ }^{\circ} \mathrm{C}$ & $\begin{array}{l}\text { Forest, } \\
\text { mineral soil }\end{array}$ & $\begin{array}{l}\text { Forest, } \\
\text { moss }\end{array}$ & $\begin{array}{l}\text { Shaded } \\
\text { (in tent) }\end{array}$ & $\begin{array}{l}\text { Shaded \& } \\
\text { cleared }\end{array}$ & Control & Cleared \\
\hline $15 \mathrm{~cm}$ (air) & Min $T$ & & 2.5 & -0.6 & -2.0 & -2.0 & -2.0 \\
& Max $T$ & & 15.2 & 30.3 & 31.5 & 35.7 & 29.9 \\
& Mean T (SD) & & $7.0(2.3)$ & $8.2(5.4)$ & $8.6(6.1)$ & $8.2(6.8)$ & $8.3(5.5)$ \\
$-3 \mathrm{~cm}$ (soil) & Min T & & 3.7 & 5.8 & 5.0 & 7.0 & 5.0 \\
& Max T & & 12.6 & 11.8 & 13.7 & 12.2 & 19.0 \\
& Mean T (SD) & & $7.1(1.5)$ & $8.4(1.2)$ & $9.1(2.0)$ & $9.4(1.1)$ & $11.3(3.4)$ \\
$-12 \mathrm{~cm}$ (soil) & Mean T (SD) & $9.2(0.3)$ & $9.9(0.1)$ & $10.8(0.3)$ & $11.6(1.4)$ & $11.8(0.5)$ & $12.7(1.0)$ \\
& & $n=5$ & $n=3$ & $n=8$ & $n=9$ & $n=19$ & $n=18$ \\
\hline
\end{tabular}

Temperatures of topsoil $(-3 \mathrm{~cm})$ and air $(15 \mathrm{~cm})$ are summaries of data recorded with dataloggers every 2 min during 7 days (13 to 20-11-2003): mean and SD of one point over time. Temperatures of the soil at $12 \mathrm{~cm}$ depth were measured once in each plot: mean and SD of several points at one time ( $n=$ number of points measured) 
ship to the treatments. In the forest the mean temperatures were consistently lower and air temperatures were less variable and less extreme than those in any of the páramo treatments. Here, moss is also abundant, because of and contributing to the high humidity. So the main aspects of the forest microclimate that the shade tents reproduce are the protection from radiation, as intended, the higher humidity, a side-effect, but not the lower and more constant temperatures. The clearing of neighbors also did not affect air temperatures, but it increased soil temperature fluctuations through increased exposition to solar radiation during the day and to radiative cooling at night.

\section{Discussion}

Most tree species did not regenerate naturally above the studied treeline. Seedlings that were transplanted into the páramo survived and grew most under artificially provided shade. Natural shade from the páramo vegetation also had a positive effect on survival, outweighing competitive effects. The effect of substrate type on seedling survival was negligible. So according to our results excess solar radiation indeed hinders tree regeneration above this tropical treeline, similar to what has been found at several temperate treelines (Ball et al. 1991; Germino and Smith 1999; Germino et al. 2002; Kitzberger et al. 2000; Maher et al. 2005; Wardle 1985).

The species that are naturally regenerating in the páramo all have adaptations to protect themselves from the direct effects of excess radiation, such as photoinhibition and overheating. Diplostephium has whitish pubescent leaves that reflect sunlight, Weinmannia rapidly turns red in sunlight due to the production of protective pigments, and Gaiadendron is orange in high light situations (pers. obs.). The preference of Gaiadendron for high-light environments is also reflected by its usual habitus: in closed forest it grows epiphytically while in open habitats it grows terrestrially (Beyer 1993; Kuijt 1963). So indeed we found that only sprouts of radiation-tolerant tree species occurred in the páramo.
Damage by excess solar radiation can occur in several forms (Valladares and Pearcy 1997). Direct damage related to over-excitation of the photosynthesis apparatus (photoinhibition, photooxidation) is aggravated by low temperatures. Plants that cool down strongly during the night are therefore particularly vulnerable to the negative effects of solar radiation in the morning (Ball et al. 1991; Lundmark and Hällgren 1987), so that exposed plants are dually affected (Germino and Smith 1999). However, the shade tents did not affect minimum soil temperatures, and minimum air temperature was higher in the shaded but not in the cleared and shaded plot. Still, seedlings showed a strong positive reaction to both shade treatments. We therefore conclude that high radiation is a more important limitation for tree seedling establishment than extreme temperatures per se. Nightly frosts certainly contribute to the adverse conditions for tree regeneration in the páramo, but mainly when they are followed by strong sunlight during the day (Ball et al. 1991; Close et al. 2000; Krause 1994).

Direct radiation damage was evident in the patterns of leaf discoloration of some of the species. This damage appeared more serious than just photoinhibition, as it caused shedding of the leaves and in most cases the death of the whole seedling. Both photooxidation and UV damage may play a role. In other species the cause of the damage appeared to be more related to overheating and desiccation, which are also caused by excess radiation. The topsoil of cleared plots warmed up more than that of other plots, but because of the good water retention capacity the páramo soil dried out only superficially. Still, because of the high water demand for transpirational cooling of exposed leaves, and because of the dryer air in the exposed plots, water stress and subsequent overheating may have negatively affected seedling performance (Smith et al. 2003; Valladares and Pearcy 1997). Although our results clearly demonstrate that radiation causes damage and hinders tree regeneration, the exact mechanisms of radiation damage in the studied species definitely need further investigation.

Most tree species regenerated naturally only in the shade of the forest. Dependence of seedlings on shade is common in many natural ecosystems 
(Callaway 1995; Pugnaire et al. 1996; Weltzin and McPherson 1999), yet it is important to realize that it also affects tropical treelines, because this intolerance to radiation can influence treeline dynamics and spatial patterns (Kupfer and Cairns 1996; Slayter and Noble 1992). It can for instance be one of the reasons why the treeline in this area is so stable, even though the potential climatic treeline may lie at a higher altitude. Such stability could involve a positive feedback between vegetation and environment, causing a 'switch' (Wilson and Agnew 1992). Shade-dependence can create a positive feedback switch because the forest provides shade, so that tree growth is favored and the forest is maintained, while the lack of shade in the páramo inhibits tree establishment so that the páramo is maintained. Such positive feedback can not only stabilize the treeline, but can also make it more abrupt (Armand 1992; Camarero and Gutiérrez 2004; Wardle and Coleman 1992; Wilson and Agnew 1992). Shadedependence of tree seedlings could therefore be an alternative or additional explanation for the abruptness of tropical treelines (Bader et al. in review; Tranquillini 1979), which is usually attributed to fire alone (Miehe and Miehe 1994).

However, in our study area tree species are present that are not shade-dependent and that could therefore stop a positive feedback based on radiation. Yet no recently established adult trees were observed in the páramo, and the treeline had not advanced for at least 40 years. This is probably due to the fires that occur regularly in the páramo. After a páramo fire the tussock grasses re-grow rapidly (Beck et al. 1986; Hofstede et al. 1995; Laegaard 1992; Wesche et al. 2000), but tree seedlings are killed or recover slowly after having been set back to ground level (pers. obs.; Wesche et al. 2000). In this way frequent fires prevent the trees' emergence from the fire trap, the flame zone of páramo fires (Bond and Keeley 2005). Seedlings can therefore not develop into adult trees, which are less vulnerable to fire, and which could provide shade for further forest development. Fire can therefore create a positive feedback switch (van Langevelde et al. 2003), just like shade-dependence can, because the moist cloud forest provides young trees with protection from fire (Kessler 2000), while the páramo provides good fuel for the fires that prevent trees from establishing (Vilà et al. 2001). The positive feedbacks resulting from shade and fire may re-enforce each other, shade-dependence slowing down forest expansion between fires, and cause a treeline to be even more stable and abrupt.

In addition to radiation and fire, there are other natural factors that might be expected to limit tree establishment above the treeline. We will discuss the role of dispersal, competition, and substrate.

Natural tree establishment strongly decreased with distance from the forest edge, yet the survival of transplanted seedlings did not decrease with this distance. Seedlings were also more abundant under the canopy of trees of the same species. Also, the most common sprouts in the páramo were Gaiadendron ramets, which do not depend on seed dispersal. The importance of clonal growth for this species can be easily observed in the field, because of its strongly clustered distribution. This all indicates that dispersal is an additional limiting factor for forest extension, as has been suggested for some temperate treelines (Cuevas 2000; Wardle and Coleman 1992).

Competition for space or other resources with páramo vegetation may take place, but at the same time seedlings depend on the facilitative effect of shading. This is true especially for transplanted Gaiadendron seedlings, even though this species was earlier concluded to be radiationtolerant. Once again, this can probably be explained by the clonal growth of this species, because ramets may only be radiation-tolerant if they have parental support, while seedlings such as those we planted may still be shade-dependent. Also the other species showed no positive effect of the removal of neighbors, so competition is not an important limitation for tree seedling establishment.

The mineral páramo soil does not appear to be a problem for tree seedlings, because seedlings did well in the páramo soil, providing they were sufficiently shaded. Also, seedlings planted in the forest did equally well in mineral soil and in the natural forest substrate. In fact, seedlings planted in this moss were sometimes almost overgrown by 
it, which probably explains partly why we measured negative growth in seedlings in the forest. This probably did not benefit them, even if it did not kill them. Seedlings in the forest therefore appear to grow in moss simply because that is the only substrate available in the forest, and not because they are favored by it.

Treelines in other parts of the tropics often have similar forest and alpine vegetation types and environmental conditions as those found in our study area (Bader et al. in review). We can therefore expect that also at other tropical treelines tree regeneration is naturally hindered by excess radiation, again in combination with low night-temperatures and limited dispersal. Anthropogenic páramo fires are also common at most treelines, and probably further hinder tree regeneration. If we assume that warmer temperatures would cause a rise in the potential treeline, three scenarios of the effects of climatic warming on actual tropical treelines are possible. First, where fires continue to be lit in the páramo, treelines will not shift upwards. Second, where fires are suppressed but no radiation-tolerant tree species are present, treelines will also not shift upwards. And third, even where fires are suppressed and some radiation-tolerant tree species are present, treelines will shift upwards only slowly. In the latter case, treelines may shift upwards even without climatic warming if they are not in equilibrium with the current climate. It is then quite plausible that (some) tropical treelines are still on their way up from their position in the last ice age, and that the use of fire in the páramo has stopped the upwards movement, rather than having caused a downward displacement of the treeline. This scenario is also suggested by recent palaeological findings in our study area (Di Pasquale et al. accepted).

The proposed effects of positive feedback switches on treeline dynamics, patterns, and historical reconstruction are largely hypothetical, and the relative importance of anthropogenic influences and natural processes will depend strongly on the local climate, species pool and land use history. However, the existence of natural processes that can, at least in theory, explain the low position, stability, and abruptness of tropical treelines, stresses the need to remain critical of the fire-dominated view most authors adopt nowadays. It also stresses the need for more research on this issue, especially fire-exclusion experiments and replications of the experiment presented here in other tropical treeline environments with different tree species.

Acknowledgments We thank Germán Vargas and the staff and volunteers of Guandera Biological Station for their help and company during the fieldwork, and Robert Hofstede and Ecopar (Quito) for their support and logistic facilitation of our research. We also thank Arnold Bregt, Chris James and two anonymous reviewers for their useful comments on the manuscript. The research of MR is supported by a VIDI grant from the Netherlands Organization for Scientific Research, division Earth and Life Sciences (NWO-ALW).

\section{References}

Armand AD (1992) Sharp and gradual mountain timberlines as a result of species interaction. In: Hansen AJ, Castri FD (eds) Landscape boundaries : consequences for biotic diversity and ecological flows. Springer, New York

Bader MY, Rietkerk M, Bregt AK in review. Vegetation structure and temperature regimes of tropical alpine treelines

Ball MC, Hodges VS, Laughlin GP (1991) Cold-induced photoinhibition limits regeneration of snow gum at tree-line. Funct Ecol 5:663-668

Barber J, Andersson B (1992) Too much of a good thing: light can be bad for photosynthesis. Trends Biochem Sci 17:61-66

Beck E, Scheibe R, Schulze ED (1986) Recovery from fire: observations in the alpine vegetation of western Mt. Kilimanjaro (Tanzania). Phytocoenologia 14:55-77

Beyer C (1993) Vergleichende morphologische und anatomische Untersuchungen zur Ontogonie der terrestrischen Loranthaceae. Biologie. Philipps-Universität Marburg, p. 232

Bond WJ, Keeley JE (2005) Fire as a global 'herbivore': the ecology and evolution of flammable ecosystems. Trends Ecol Evol 20:387-394

Callaway RM (1995) Positive interactions among plants. Bot Rev 61:306-349

Callaway RM, Brooker RW, Choler P, Kikvidze Z, Lortie CJ, Michalet R, Paolini L, Pugnaire FL, Newingham B, Aschehoug ET, Armas C, Kikodze D, Cook BJ (2002) Positive interactions among alpine plants increase with stress. Nature 417:844-848

Camarero JJ, Gutiérrez E (2004) Pace and pattern of recent treeline dynamics: Response of ecotones to climatic variability in the Spanish Pyrenees. Clim Change 63:181-200

Choler P, Michalet R, Callaway RM (2001) Facilitation and competition on gradients in alpine plant communities. Ecology 82:3295-3308 
Close DC, Beadle CL, Brown PH, Holz GK (2000) Coldinduced photoinhibition affects establishment of Eucalyptus nitens (deane and maiden) maiden and Eucalyptus globulus labill. Trees-Struct Funct 15(1):32-41

Cuevas JG (2000) Tree recruitment at the Nothofagus pumilio alpine timberline in Tierra del Fuego, Chile. J Ecol 88:840-855

Di Pasquale G, Marziano M, Impagliazzo S, Lubritto C, De Natale A, Bader MY accepted. The Holocene treeline in the northern Andes (Ecuador): first evidence from soil charcoal. Palaeogeogr Palaeoclimatol Palaeoecol

Ellenberg H (1996) Paramos und Punas der Hochanden suedamerikas, heute grossenteils als potentielle Waelder anerkannt. Verhandlungen der Gesellschaft für Oekologie 25:17-24

Germino MJ, Smith WK (1999) Sky exposure, crown architecture, and low-temperature photoinhibition in conifer seedlings at alpine treeline. Plant Cell Environ 22:407-415

Germino MJ, Smith WK, Resor AC (2002) Conifer seedling distribution and survival in an alpine-treeline ecotone. Plant Ecol 162:157-168

Hamilton LS, Juvik JO, Scatena FN (1995) Tropical montane cloud forests. Springer Verlag, New York

Hemp A, Beck E (2001) Erica excelsa as a fire-tolerating component of Mt. Kilimanjaro's forests. Phytocoenologia 31:449-475

Hofstede R, Segarra P, Mena Vásconez P (eds) (2003) Los páramos del Mundo. Proyecto Atlas Mundial de los Páramos. Global Peatland Initiative/NC-IUCN/EcoCiencia

Hofstede RGM, Chilito EJ, Sandovals EM (1995) Vegetative structure, microclimate, and leaf growth of a paramo tussock grass species, in undisturbed, burned and grazed conditions. Vegetatio 119:53-65

Holtmeier FK (1994) Ecological aspects of climaticallycaused timberline fluctuations, review and outlook. In: Beniston $M$ (ed) Mountain environments in changing climates. Routledge, London; New York, pp 220-233

Huner NPA, Öquist G, Sarhan F (1998) Energy balance and acclimation to light and cold. Trends Plant Sci 3:224-230

Kessler M (1995) Present and potential distribution of Polylepis (Rosaceae) forests in Bolivia. In: Churchill SP, Balslev H, Forero E, Luteyn JL (eds) Biodiversity and conservation of Neotropical montane forests, Proceedings of the neotropical montane forest biodiversity and conservation symposium. New York Botanical Garden, pp. 281-294

Kessler M (2000) Observations on a human-induced fire event at a humid timberline in the Bolivian Andes. Ecotropica 6:89-93

Kessler M (2002) The "Polylepis problem": where do we stand?. Ecotropica 8:97-110

Kitzberger T, Steinaker DF, Veblen TT (2000) Effects of climatic variability on facilitation of tree establishment in northern Patagonia. Ecology 81:1914-1924
Körner C, Paulsen J (2004) A world-wide study of high altitude treeline temperatures. J Biogeogr 31:713-732

Krause GH (1994) Photoinhibition induced by low temperatures. In: Baker NR, Bowyer JR (eds) Photoinhibition of photosynthesis-from molecular mechanisms to the field. BIOS Scientific Publishers, Oxford, pp 331-348

Kuijt J (1963) On the ecology and parasitism of the Costa Rican tree mistletoe, Gaiadendron punctatum (Ruiz \& Pavon) G Don. Can J Bot 41:927-936

Kullman L (2001) 20th century climate warming and treelimit rise in the Southern Scandes of Sweden. Ambio 30:72-80

Kupfer JA, Cairns DM (1996) The suitability of montane ecotones as indicators of global climatic change. Prog Phys Geog 20:253-272

Laegaard S (1992) Influence of fire in the grass páramo vegetation of Ecuador. In: Balslev H, Luteyn JL (eds) Páramo. An Andean ecosystem under human influence. Academic Press, London, pp 151-170

Long SP, Humphries S, Falkowski PG (1994) Photoinhibition of photosynthesis in nature. Annu Rev Plant Physiol Plant Mol Biol 45:633-662

Lundmark T, Hällgren JE (1987) Effects of frost on shaded and exposed spruce and pine seedlings planted in the field. Can J For Res 17:1197-1201

Maher EL, Germino MJ, Hasselquist NJ (2005) Interactive effects of tree and herb cover on survivorship, physiology, and microclimate of conifer seedlings at the alpine tree-line ecotone. Can J For Res 35:567574

Miehe G, Miehe S (1994) Zur oberen Waldgrenze in tropischen Gebirge. Phytocoenologia 24:53-110

Pugnaire FI, Haase P, Puigdefabregas J (1996) Facilitation between higher plant species in a semiarid environment. Ecology 77:1420-1426

Pugnaire FI, Luque MT (2001) Changes in plant interactions along a gradient of environmental stress. Oikos 93:42-49

Slayter RO, Noble IR (1992) Dynamics of montane treelines. In: Hansen AJ, di Castri F (eds) Landscape boundaries: consequences for biotic diversity and ecological flows. Springer, New York, pp. 346-359

Smith WK, Germino MJ, Hancock TE, Johnson DM (2003) Another perspective on altitudinal limits of alpine timberlines. Tree Physiol 23:1101-1112

Tranquillini W (1979) Physiological ecology of the Alpine timberline : tree existence at high altitudes with special reference to the European Alps. Springer, Berlin

Valladares F, Pearcy RW (1997) Interactions between water stress, sun-shade acclimation, heat tolerance and photoinhibition in the sclerophyll Heteromeles arbutifolia. Plant Cell Environ 20:25-36

van Langevelde F, van de Vijver C, Kumar L, van de Koppel J, de Ridder N, van Andel J, Skidmore AK, Hearne JW, Stroosnijder L, Bond WJ, Prins HHT, Rietkerk M (2003) Effects of fire and herbivory on the stability of savanna ecosystems. Ecology 84:337-350

Vilà M, Lloret F, Ogheri E, Terradas J (2001) Positive firegrass feedback in Mediterranean Basin woodlands. For Ecol Manage 147:3-14 
Wardle P (1985) New Zealand timberlines. 1. Growth and survival of native and introduced tree species in the Craigieburn Range, Canterbury. N Z J Bot 23:219234

Wardle P, Coleman MC (1992) Evidence for rising upper limits of four native New Zealand forest trees. N Z J Bot 30:303-314

Weltzin JF, McPherson GR (1999) Facilitation of conspecific seedling recruitment and shifts in temperate savanna ecotones. Ecol Monogr 69:513-534
Wesche K, Miehe G, Kaeppeli M (2000) The significance of fire for afroalpine ericaceous vegetation. Mt Res Dev 20:340-347

Wille M, Hooghiemstra H, Hofstede R, Fehse J, Sevink J (2002) Upper forest line reconstruction in a deforested area in northern Ecuador based on pollen and vegetation analysis. J Trop Ecol 18:409-440

Wilson JB, Agnew ADQ (1992) Positive-feedback switches in plant communities. Adv Ecol Res 23:263336 